Vol. 10, n² | 2006

Varia

\title{
Emotions on Trial: Judging Crimes of Honour in Post-Civil-War Greece
}

Efi Avdela

\section{(2) OpenEdition \\ Journals}

Electronic version

URL: https://journals.openedition.org/chs/371

DOI: $10.4000 /$ chs.371

ISSN: 1663-4837

Publisher

Librairie Droz

Printed version

Date of publication: 1 December 2006

Number of pages: $33-52$

ISBN: 978-2-600-01129-7

ISSN: 1422-0857

\section{Electronic reference}

Efi Avdela, "Emotions on Trial: Judging Crimes of Honour in Post-Civil-War Greece", Crime, Histoire \& Sociétés / Crime, History \& Societies [Online], Vol. 10, n² | 2006, Online since 01 January 2010, connection on 22 March 2022. URL: http://journals.openedition.org/chs/371 ; DOI: https://doi.org/ $10.4000 /$ chs.371

This text was automatically generated on 22 March 2022.

(c) Droz 


\title{
Emotions on Trial: Judging Crimes of Honour in Post-Civil-War Greece
}

\author{
Efi Avdela
}

1 «Honour crime in Piraeus committed by soldier,» ran the title of a news story published in an Athens morning newspaper on 21 September 1951. According to the report, on the previous day, Panos Marmaris, a 22-year-old boilermaker doing his military service and a resident of Itea (near Delphi), shot his fellow-townsman, Andreas Triandafyllou, aged 32, at his kiosk in the Kaminia district of Piraeus. The perpetrator considered the victim the «seducer» of his 19-year-old sister Maria, whom he had made pregnant and whom he refused to marry. Marmaris, who had repeatedly tried to persuade the kioskowner to change his mind, had travelled to Piraeus for yet another meeting «in order to settle the difference between the two families,» which concerned «the contentious issue of the reinstatement of his relations [...] with the perpetrator's sister, who had given birth to [the victim's] child.» Faced with Triandafyllou's categorical refusal and his provocative behaviour, Marmaris, «beside himself,» killed him. When he was arrested, «he invoked the usual reasons of honour,» while «he reproached the victim, to whose provocations he attributed the tragedy that took place»².

2 News items such as these are typical of 1950s Greece. Throughout that decade, but also into the early sixties, Athenian newspapers carried a significant number of reports on crimes (murders, injuries and attempted murders) committed «for reasons of honour," according to the repeated, stereotypical wording. This is a particular non-specific category of acts of interpersonal violence, for which the perpetrator invokes the restitution of an insult against her/his family or individual honour, an insult which was allegedly caused by the actions of the victim. In most cases, these actions revolve around marriage and family, either as something anticipated or as something to be preserved ${ }^{3}$.

3 Of course, this was not a new phenomenon. As early as the $19^{\text {th }}$ century, the insult to one's «honour» constituted the main justification for the commission of acts of interpersonal violence and this does not appear to change significantly during the first half of the $20^{\text {th }}$ century ${ }^{4}$. However, there are two features which distinguish the post- 
civil-war period. On the one hand, the acts of interpersonal violence which are termed, by those directly involved, "honour crimes» are delimited by the specific meaning mentioned above. On the other hand, at this time, «honour crimes» dominated an unprecedented public debate. The debate extended beyond «honour crimes» to include the more general issue of the management of interpersonal violence, the forms and extent of which had been deeply marked by the previous ten years. The War, the German occupation, and the Civil War had brought about, in the forties, a familiarisation with violence which was visible in many aspects of everyday life for several years after the end of the military conflicts 5 . In the early 1950s, the victors in the Civil War proceeded to reinstate order. This was a conjuncture at which public opinion became increasingly concerned with the «crime rate». Foreign anthropologists began pointing out for the first time the meaning of social values such as «honour» in Greek society ${ }^{6}$ and the content of this concept underwent a redefinition process. By the late 1960s this process had led to a transformation and a delegitimisation of the meaning of «honour» which constitutes the normative basis of honour crimes; i.e. the delegitimisation of the correlation between the defence of the offended honour and interpersonal violence. The transformation of the meaning of «honour,» which would lead to the abolition of «honour crimes,» by the end of the 1960s, is linked to a broader concern over the character and the particular values of Greek society during a period of rapid social change.

In this paper, I intend to focus on one of the dimensions of the study of «honour crimes» in Greece during the fifties and sixties, and specifically on their judicial management. My analysis will focus not only on the debate concerning the role of jurors in «honour crime» trials, but also the administration of penal justice in general. I hope that this analysis will show, through the case of Greece, the ways in which the administration of justice is subject to a particular conjuncture, i.e. that it is the result of changing perceptions and cultural beliefs, and is therefore historically defined ${ }^{7}$.

\section{Jurors and «the Public Feeling of Justice»}

5 «Honour crimes» do not constitute a separate judicial category under the Greek Penal Code $^{8}$. Related cases are introduced in court among other "crimes against life» (homicides or attempted homicides or grievous bodily harm) ${ }^{9}$. The reference to «reasons of honour» during the trial is significant only in relation to the (male or female) perpetrator's motives in that their acknowledgement can provide the defendant with mitigating circumstances. In other words, in such cases the court is not called upon to rule as to the perpetrator's guilt with regard to the criminal act she or he has committed. This is an accepted fact to which the defendant has confessed. What is at stake is the motive - whether the invocation of the insult against one's honour is valid.

In essence, the court is called upon to judge to what degree the (male or female) victim, through her or his actions, offended the reputation of the perpetrator so as to provoke a strong sense of shame and to impel her or him to violence. The judgment on this matter is decisive in the outcome of the trial, since it influences the degree to which the court takes into account any mitigating circumstances, especially those which link the perpetrator's reputation to the intensity of the emotional disturbance caused by the victim's insult to her or his honour. The body that decides whether the perpetrator 
of an «honour crime» is entitled to a more lenient sentence due to mitigating circumstances is the jury. The court passes its sentence based on this jury verdict.

The stance and the decisions of the jurors in «honour crime» cases were, during the fifties and sixties, at the centre of intense discussion and controversy. The debate surrounding this issue was expressed in court by public prosecutors as well as in the press, both in daily and periodical publications, by journalists, commentators, analysts and jurists. Often, in fact, the problematic penal management of «honour crimes» was correlated to the supposedly increasing crime rate in Greek society ${ }^{10}$ and the inadequacies of the system for the administration of justice. These public interventions share a concern over the role of the jurors as representatives of «accepted morals» and the sensus juris communis, «the public feeling of justice». That is to say, to what extent, through their verdicts in trials of «honour crimes,» do jurors actually fulfil this role? For jurists, court officials, criminologists, journalists and analysts, «honour crimes» and their penal management became a classic example of a field where tradition and modernisation clashed, since they brought to the surface a critical question. Had «accepted objective social morals» remained the same, or had they changed? Or, even more significantly, were they in need of change?

9 Therefore, during the period under examination, the jury is at the centre of the criticism aimed not only at the trying of «honour crimes,» but also at the workings of the penal system in general. Public prosecutors, jurists and journalists accused juries of showing a leniency which either no longer expressed «the public feeling of justice» or which did, but as a symptom of retrogression and insufficient civilisation. It was no longer taken for granted that perpetrators and jurors actually shared a common value system, or that they perceived the meaning of honour in the same way. One no longer encountered statements such as the one we come across in the periodical Noumas, in 1908: «Two terrible crimes in a single week; a father killed his son and a brother killed his sister. Regarding the latter, there is not much one can say. As terrible as it is, it also has its bright side, since it proves that the feeling of family honour is still alive among the working classes, a feeling which [...] remains sacrosanct to the Greek people and serves to conceal certain other flaws» ${ }^{11}$. In the fifties and sixties, more and more voices saw precisely in this «feeling» one of the most serious «flaws» of Greek society.

10 In effect, the discussion on mitigating circumstances and the role of the jurors constituted the first time during the post-war period that the motive invoked by the perpetrators of «honour crimes,» i.e. the insult and the emotional tension with which it is perceived, was called into question. What was in fact called into question was one of the main features of such cases - the victim's responsibility for her or his fate. What was contested was not only whether the perpetrator had the right to invoke offended honour as a mitigating circumstance in regard to the criminal act, but more importantly, the very emotion that the perpetrator put forward as her or his motive, i.e. the shame and turmoil felt at the insult.

11 Within this context, the debate and public statements surrounding the role of the jury in «honour crime» trials have two sides. The first concerns the legal structure of honour as an emotion, intervening at the moment of the criminal act, and its evaluation by the jury as a mitigating circumstance. The second refers to the correlation between the supposed leniency of the jury and the workings of penal justice in the 1950s and the 1960s Greece. 


\section{Emotions and Mitigating Circumstances} of an «honour crime» (whether male or female) often invoked not only the insult caused by the actions of the (male or female) victim over time, but also, and indeed primarily, the loss of control caused by the victim's conduct at the moment the incident took place: «I was infuriated,» «the blood rushed to my head,» «I flew off the handle,» «I saw red,» and «I was enraged,» were all common statements in the defendants' pleas ${ }^{12}$. This sudden over excitation of the perpetrator's feelings was attributed to especially insulting gestures, words or forms of conduct on the part of the victim at the precise moment of the incident. These were presented as the culmination of a long process of insults which transform the incident into an «honour crime». Exactly what provoked the emotional reaction of the perpetrator each time varied according to the relationship between the perpetrator and the victim and the history of their conflict.

More specifically, the momentary loss of control usually invoked by the perpetrators of «honour crimes» to justify their act took on meaning - for the perpetrators themselves, for the court, and for public opinion - only if seen in the light of history, i.e. over time. Only then did it become something beyond the perpetrators' control, something for which they were not responsible, and a loss of control which would not be likely to occur outside the conditions of the particular event. The more protracted the dispute between perpetrator and victim, the more inevitable and therefore legitimate was the loss of control at the moment of the crime.

We can take as an example the relationship between Periclis Gravias, his daughter Eleftheria and Iakovos Koumas. Gravias was a customs official, his daughter, Eleftheria, a teacher, and Iakovos Koumas her fiancé, an officer and teacher who refused for seven years to marry her. They were all residents of Athens. It is only in direct correlation to the different phases of this long and turbulent relationship that one can understand the intensity of the final scene, as described by the perpetrator in his plea. «Upon my refusal [to allow his daughter to follow the victim], he [Koumas] said 'I'm taking her with me. Come on, Lela, let's go,' my daughter started to put on her coat, and then I flared up, I was blinded, all I could see were stars and sunlight, I took the knife from the kitchen and I stabbed him.» The court's ruling, which acknowledged his state of "complete confusion» and acquitted him, was based precisely on the long chain of events which led - justifiably, according to the court - to the perpetrator's losing control: the loss of control was only the symptom ${ }^{13}$.

A similar case, also in Athens, was that of Stavros Kechriotis, a carpenter and real estate agent, who killed his daughter Maria because she «led a dissolute life.» If the moment of the murder could be justified by the loss of control brought on by his rage at her behaviour during their argument, his extreme reaction could only be understood in relation to the details of his long-standing efforts to «steer her to the straight and narrow path»: "On the day of the murder, her mother asked her for the keys to the shop and she threw them at her, cursing her. I tried to reason with her, but she was cursing me and in the end she threw the ashtray in my face. Beside myself with anger, I grabbed the gun and killed her.» Based on the entire story, the court acknowledged that he was in a «fit of rage» (se vrasmo psychikis ormis), accepted a plea of diminished

Crime, Histoire \& Sociétés / Crime, History \& Societies, Vol. 10, n² | 2006 
responsibility and the mitigating circumstances of having been «driven by the inappropriate behaviour of the victim,» and condemned him to five years and two months in prison ${ }^{14}$.

16 Thus, it becomes clear that in cases of «honour crimes» the jury was called upon to decide to what extent the perpetrator was driven to commit the crime by the overall behaviour of the victim which was offensive to her or his honour. That is to say, to what extent did the nature of the victim's behaviour provoke in the perpetrator such intense and justifiable emotions that it was impossible for her/him to keep her/his temper and so, as a result, she/he lost control of her/his actions and committed the crime? It concerns the formulation of «mitigating circumstances,» the acknowledgement of which directly influenced sentencing within the framework of the margin provided by the law. The significance of mitigating circumstances in the penal procedure means that the focal point becomes the study of the personality of both perpetrator and victim, in order to substantiate, on the one hand, the legitimacy of the former to invoke her/his offended honour and, on the other, the responsibility of the latter for her/his fate.

During the period under examination, penal law distinguishes between premeditated homicide which is punishable by life in prison or death, and homicide «decided and committed in a 'fit of rage',» which is punishable by imprisonment ${ }^{15}$. But what is this «fit of rage» (vrasmos psychikis ormis) and how is it defined? One of the leading criminologists of the time explained: "The 'fit of rage' is the sudden and abrupt overexcitement of one's emotions, such as anger, fear, self-esteem, jealousy, etc. There are various degrees of fits of rage, but only the highest excludes liability [...] A fit of rage (vrasmos psychikis ormis) is distinguished from passion (pathos). Passion is the powerful and continuous tendency towards achieving a certain goal, e.g. the passion for revenge, the passion of ambition or love. The existence of this passion as the cause of a certain act does not remove liability. However, at a given moment, passion may drive the person possessed by it to a state of furore which would exclude liability» ${ }^{16}$.

Thus, vrasmos psychikis ormis and pathos are both emotions, but different ones. In any event, they both display gradations which determine the degree of liability of the person acting under their influence. Therefore, the intensity of the emotion determines the degree of the perpetrator's responsibility, and, consequently, the severity of her or his sentence. Diminished liability or the lack thereof, complete or partial confusion of consciousness are all provided for by the law. But how does one measure the intensity of these emotions, and how does one distinguish between them? Who decides issues that directly concern the perpetrator's emotional state at the moment of the crime, and with what qualifications?

19 In the European tradition of penal justice, as analysed by Michel Foucault, the move from revenge to the punishment of the guilty and, subsequently, from the crime to the criminal is inseparably linked to the forming of new fields of power-knowledge, at the centre of which lies the personality of the perpetrator. Criminologists, psychiatrists, coroners and all kinds of experts intervene in court and the «mitigating circumstances» surrounding the sentence are based on their expert opinion of the perpetrator ${ }^{17}$. In the Greek penal system, determining liability does not necessarily require the intervention of a psychiatrist. The court decides whether it is a case of a fit of rage, of diminished liability, or of a state of partial or complete confusion on the part of the perpetrator at the moment of the crime. It is only in cases of a diagnosed, severe 
mental disease, due to which the perpetrator cannot be held liable, that the law provides that she or he be led to a psychiatric institution rather than prison ${ }^{18}$. With the limited intervention of «experts» during the period under examination and consequently, with minimally developed fields of "power-knowledge,» which elsewhere had been set up as early as the previous century, the role of the jurors in the Greek penal system took on great importance. It was they who were called upon to assess the mitigating circumstances put forward by the perpetrator.

In «honour crimes,» the fit of rage (vrasmos psychikis ormis) is the first mitigating circumstance invoked by the perpetrator in her or his defence, and it refers to the behaviour of the victim at the moment the act was committed. As the main mitigating circumstance, a fit of rage diminishes the sentence according to the intensity of the mental pressure (or the conscientious dilemma) experienced by the perpetrator. It refers to the instantaneous nature of the murder which is identified with the violence itself of the emotion contained in the fit of rage. In an "honour crime,» murder is emotion. However, the insult which provokes this emotion, in most cases is not instantaneous but works over time, protractedly, and that is why it is able to provoke a derangement of consciousness, a state of complete or partial confusion. In this respect, «fit of rage» and «confusion» refer to different temporalities of the «honour crime.»

21 The Penal Code provides further mitigating circumstances which concern not the act per se, but the perpetrator. These include «a previously honest life,» «the non petty motives of the act,» «improper behaviour on the part of the victim,» «rage or violent sorrow caused by an unjustified attack,» «sincere remorse,» and "good behaviour following the crime». Criminologists consider the nature of the mitigating circumstances listed in the Penal Code to be indicative of the relationship between penal law and the perceptions surrounding morality - they are constantly interacting. For example, «non petty motives are those that do not go against the common conscience regarding morality or social order», while «improper behaviour on the part of the victim» consists in the insult or even the deriding, rude gesture that the victim makes towards the perpetrator, to which the perpetrator reacts with the crime. All jurists agree that mitigating circumstances are determined by diverse factors, such as «reasons of honour, local customs, the heat of jealousy, financial misadventures, respect, mere suggestion, etc., and, generally, any other circumstance related to the perpetrator's personality ${ }^{19}$. In a penal trial, therefore, the court is called upon to rule on issues that do not refer simply to factual data in the strict sense, but also to emotions, which are vaguely defined and fluid, or to social values that change over time. The court is called upon to make a judgement based on the «feeling of the average person,» on experience, and not on prescribed scientific knowledge. This applies even more so in the trial of an «honour crime,» for which the perpetrator, from the outset, invokes powerful emotions, continuous or instantaneous, which the court must assess based on an average experience with regard to perceptions concerning moral order and with regard to the consequences of the sudden over excitation of the emotions in the cases in which this order is disturbed.

According to the Preamble of the Act of the new Penal Code in 1950, penal law provided Greece with "on the one hand, a renewal of the legal doctrine of our penal law according to the findings of the modern penal justice. On the other, it satisfied the central demand of contemporary anti-crime policy - the individualisation of the legal treatment of the person who has committed the crime» ${ }^{20}$. In the text of the law, the 
modern developments of jurisprudence are identified with the individualisation of the penal treatment of the criminal. Thus we can claim that even during the period under examination, the development of scientific knowledge and its interweaving with the penal system as a technology of power remained extremely limited in Greece. The judicial management of «honour crimes» allows us to perceive a situation in which power individualises those upon which it is exercised, without, however, becoming anonymous or functional or, at least in this field, repressive ${ }^{21}$. In this situation, the margins for contrasting interpretations with tangible penal consequences prove to be significant. Apart from the perpetrators and the victims as well as the witnesses for the defence and the prosecution, an important factor at the level of interpretation is also the jury.

Seen in this light, it is also clear that those who invoked a «fit of rage» as a defence, took it for granted that the police, the magistrate, the judges and the jurors understood what was being talked about. This can be seen in the systematic and repeated invocation on the part of the perpetrator of her or his unsettled emotional state at the time of the trial. It can also be seen in the defence strategy that aims to secure the defendant the mitigating circumstances of being in a «fit of rage» and in a «partial» or "complete state of confusion». Thus if they understood and recognised the emotions invoked by the perpetrator, they also recognised the situations that could have provoked them as different forms of insult against one's honour. An example would be the disputing of the authority of the male leader of the family and a blow to the public image of the perpetrator that this brought about in the examples mentioned above.

According to this rationale, the perpetrators of «honour crimes» and the juries that tried them shared the same meaning of honour and this common cultural system often supplanted other differences such as those of class or education. Even though all jurists agreed that the law does not define what «honour» ${ }^{22}$ is, this common cultural premise, which was viewed as «shared values,» was considered responsible for the jury's leniency in cases of «honour crimes.»

It is not possible to factually substantiate a charge against the jury for leniency, neither generally nor specifically, in cases of «honour crimes.» Based on the information at our disposal, we can perhaps claim that in the cases in which the jury's verdict recognised a complete or partial state of confusion on the part of the perpetrator as stemming from the victim's behaviour at the moment of the incident, the relative statements, as they appeared in "penal issues» ${ }^{23}$, were indicative of this shared system of cultural values. Guilty of intentional homicide committed in a fit of rage, was the jury's decision in the case of the woman farmer who, in 1952 murdered her fellow-villager in Frantzi, prefecture of Fthiotida, because he had seduced her. The rationale of the jury was that «at the time when she committed the above act, because of a derangement of her consciousness, due to rage, provoked in her by the insult to her honour by the victim, she may not have fully lacked the ability to perceive the injustice of her action or to act according to this perception, however her ability was significantly diminished as a result of the above cause.» And the court issued a prison sentence of four and a half years ${ }^{24}$. «Guilty of manslaughter [...] but in a state of complete confusion,» was the jury's verdict in the case of Periklis Gravias. In 1953, in Nea Erythrea, he murdered his daughter's fiancé because for seven years he kept breaking his promise to marry her. Gravias was «enraged by this behaviour of [the victim], by which yet another calamity was being forced upon his family, which, from a moral standpoint, had collapsed to 
such a degree that he could not distinguish the injustice of his action, and, being in such a mental state, he committed the offence in question.» Based on this verdict, Gravias was «acquitted of any penalty» ${ }^{25}$. Ioannis Niotis was found guilty of being «in a fit of rage because of the indignation caused by the immoral conduct of the victim and the abandoning on her part of her three underage children,» with the mitigating circumstances of «a previously honest private, familial, professional and overall social life». In 1954, Niotis fatally wounded his sister in Piraeus because she was «living a dissolute life». He was sentenced to two years and fifteen days in prison ${ }^{26}$. The verdict in the case of Antonia Matsidou, a cleaning woman, was that she was guilty of intentional homicide with diminished liability, «due to an unhealthy derangement of her mental functions, due to stupidity,» with the mitigating circumstances of a previously honest life and the fact that she showed «sincere remorse». She "was prompted by the inappropriate behaviour of the victim and got carried away by rage and violent sorrow, caused by an unjust act committed against her». In 1962 she killed stretcher-carrier Nikos Kataras in Athens because he refused to marry her. She was sentenced to thirteen years imprisonment ${ }^{27}$.

On the other hand, an overall - although impressionistic - view of the 1950s and 1960s shows a decrease in verdicts citing a state of partial or complete confusion. There is also an increase in maximum sentencing for the same crime and taking into account the same mitigating circumstances provided by the law. Any leniency appears to be giving way to increasing severity in the enforcement of the law. However, it remains extremely difficult to substantiate a convincing assessment of the treatment received in court by those accused of «honour crimes». The difficulty of clearly defining the role of the jurors is due to a variety of factors. The main one has to do with the principle of individualising the sentence provided by the law which bases the apportionment of the sentence on the specific data of a case in such a way that no case is like another ${ }^{28}$.

In fact the matter is quite irrelevant. The way in which jurors were perceived by journalists, analysts and judges had very little to do with their actual severity or leniency, no matter what our difficulties in assessing it. The fact that their attitude became, during the period under investigation, the subject of public debate is more than anything else indicative of the cultural transformation that is characteristic of the time. In the juridical domain, this cultural transformation took the form of the break with the consensus that jurors were by definition representative of sensus juris communis. The question as to what extent perpetrators and jurors shared common values and recognised common emotions lay at the centre of this debate. Not only this common ground was not considered self-evident any more, but the question was raised as to whether it was in fact desirable for securing the public feeling of justice and the public's confidence in penal justice; or furthermore, whether this common ground could ever exist.During the period we are studying (unlike previous ones), commentaries never congratulated the jurors on their decisions regarding «honour crimes» or encouraged them to continue to deal justly with the social problems to which these crimes were linked. "Certainly above all approbation is the pardon given to Kalli Vlastari of Kythnos, accused of murdering the traitorous lover who abandoned her. Bearing in mind the moral depravity of certain vile individuals who systematically and premeditatedly destroy the reputation of honourable families and the lives and happiness of innocent, unfortunate beings, the jury, through its acquittal of the unfortunate Kalli, has struck a blow against this gang of cowards,» wrote Kallirroi 
Parren in $1888^{29}$. Conversely, during the next century, in the fifties and sixties, jurors were systematically blamed for everything that was wrong with penal justice.

\section{The Jury on Trial}

Initially, criticism originated from legal circles. Public prosecutors addressed the court in cases of "honour crimes;» penal law experts commented on the inadequacies of penal justice and proposed measures for dealing with them and criminologists sought the preconditions that would improve the situation. «There is something rotten. The constantly invoked reasons of honour carry a lot of weight here. When trying a crime committed for reasons of honour, the hearts of the gentlemen of the jury become soft, and are transformed into honey,» stated public prosecutor Rakopoulos at the trial of the Lakopoulos brothers from the village of Sagiades, prefecture of Arta. In 1954 the brothers killed a fellow-villager because he would not agree to marry their sister whom he had seduced. The journalist following the trial described the public prosecutor's statement as a «momentous event,» and a «relentless indictment brought on by the recently observed tendency of juries to acquit the defendants $»^{30}$.

During the same year, the workings of trials by jury and the verdicts of the jurors in cases of «honour crimes» had come to the fore for the added reason of the legislative adjustment giving women the right to participate in juries. This adjustment was the logical, albeit delayed, consequence of the bestowing of political rights upon women in 1952, as well as of the ratification by the Greek parliament of the international convention "concerning the political rights of women,» in 1953. The prospect and the elaboration of the adjustment caused strong reactions on the part of the Bar and the judiciary ${ }^{31}$.

The central question concerned the ability of women to distinguish between pity and justice. The judges maintained that criminal courts try crimes «which demand that the person judging be isolated from the sensitive chords of human pity as well as from indecision». According to the public prosecutor of the Supreme Court of Appeal, «we fear that perhaps woman, [...] created by nature with more sensitivity, as we believe, than man, will not be able to face, with the same realism as he, the need to punish a crime with, at times, a harsh sentence. Besides, the statistics of the verdicts of criminal courts under the present composition of the juries proves that this institution is, if not bankrupt, certainly not successful with regard to the intentions of the constitutional legislator, since, as a rule, the jury's verdicts are extremely lenient and not equal to the severity of the committed crime, while sometimes acquitting the defendant unjustifiably.» The participation of women risked rendering the institution «even more vulnerable» ${ }^{32}$.

31 The issue then concerned the relation of each sex to emotions. But it also equally concerned the contrasting of emotion with reason - the reason of jurisprudence, not of «common sense». For if women were considered emotional by nature, then male jurors were also accused of getting carried away by their emotions. "It is usually said that jurors get carried away by their emotions and that the result of this is the leniency that they display which constitutes a vulnerable spot in the institution of the jury» ${ }^{33}$. Those who claimed that the innate emotionality of women would reinforce the unacceptable leniency of juries were countered by different arguments within the framework of the same common acceptance. For Aglaia Tsitsoura, one of the first women criminologists, 
the answer was defined by two obvious givens. On the one hand women do indeed have a more developed emotional world because of their maternal instinct, and on the other, the jury expresses the "popular conscience». It is inferred therefore that «since [...] the jury's verdict expresses the subjective judgment of the representatives of the Greek people, it is not only advisable but also necessary for women to participate in juries,» since this guaranteed the representation of the perceptions and emotions of the entire population and not only of men ${ }^{34}$.

The need for women's emotions and values to be represented on juries was implied by the introductory report to the relevant legislative decree. «In the case of especially heinous crimes, it can be said that a woman's judgment will be more objective and fair, and offences such as the insulted honour of an uncle or male cousin (...!) [sic] will, in the person of a female juror, meet with a fairer penal treatment and retribution $»^{35}$. In an official text, the correlation between female jurors and «honour crime» trials made highly controversial issues appear as common acceptances: that the invocation of «reasons of honour» in felony crimes could not be accepted; that «honour crimes» were directed primarily against women; and that male jurors did not actually possess sounder judgment than women, who were able to judge equally, if not more objectively ${ }^{36}$.

The participation of women on a jury (three out of ten) was considered generally successful, even though accusations of inadmissible leniency on the part of juries continued unabated ${ }^{37}$. Indeed, in 1960, a penal law expert claimed that thanks to the improved composition of juries and the participation of women, «the spirit of leniency which prevailed in the past in the case of 'honour crimes' has finally been limited». Thus, «the time when such verdicts were issued, as once occurred in my birthplace, Crete, where a man who murdered his mother-in-law for reasons of 'honour' was acquitted by the Criminal Court, belongs irrevocably to the past! $»^{38}$.

Nevertheless, most of his colleagues as well as other social commentators were still a long way from sharing this view until the late 1960s. They did not tire of repeating that juries showed inadmissible leniency towards criminals, causing the reaction of public opinion.

Certain jurists correlated the problem with the general application of mitigating circumstances provided by the law in the case of homicides, which «constitutes a danger of issuing inadmissibly lenient verdicts». More serious misunderstandings were caused by mitigating circumstances concerning «a fit of rage,» «non petty motives» and the «inappropriate behaviour of the victim» because "the jurors think that these concepts (fit of rage, non petty motives, an honourable life, etc.) are sufficiently clear and that any explanation is considered superfluous, if not suspect and misleading» ${ }^{39}$. For the same reason, a lack of restraint was observed in the application of the «state of partial confusion». However, it was emphasised that these concepts were extremely complex and that the emotions they referred to were especially difficult to understand in their correct intensity and meaning by non-experts. And since the jurors were insufficiently prepared to scientifically comprehend the meaning of mitigating circumstances, they interpreted them according to their current meaning, resulting in their scandalously lenient decisions. The jurors' «lack of restraint» was such, certain jurists claimed, that it went against «the public feeling of justice» ${ }^{40}$. The reality of this public feeling concerning justice was, of course, much more complicated in such a period of intense social and political unrest. 

leniency. Each new crime or trial brought on a flood of commentaries and analyses. Well-known commentators and columnists repeatedly criticized the institution of the jury, and they were often provoked by the verdicts of juries in cases of «honour crimes». One example is the Mayer Street crime in 1960, in which carpenter Nikolaos Kakouris killed his sister, her boyfriend and his mother because the young man and his mother reneged on their promise of marriage given to the young woman's family. Commenting on this crime, sociologist, journalist and social commentator Theophylaktos Papakonstantinou described the perpetrator as «primitive, incapable of feeling pity, incapable of resisting the wind of insanity blowing in his home, and influenced by his immediate and greater environment.» «Jury decisions usually encourage these types, because there is no awareness yet in this country that so-called 'honour crimes' are the most dishonourable of crimes»"

Theophylaktos Papakonstantinou systematically kept returning to the issue. A typical case of an organic intellectual of that period and a representative of the authoritarian modernisation that marked it, his regular attacks (as those of several jurists of the time) often targeted the jury system, i.e. the participation of jurors as representatives of the people. Even though it was never mentioned by name, the relatively recent experience of the popular justice of the 1940s emerges between the lines of his writings as the extreme version of the system he is denouncing ${ }^{42}$.

38 Papakonstantinou believed that the «lack of restraint» of the jurors blatantly contradicted the state policy against criminality. Not only were the sentences provided by the law for certain crimes already lenient; not only were these lenient sentences never served to term; but those who decided on a defendant's guilt and sentence were the jurors, thus making their role more decisive than that of the judges ${ }^{43}$.

39 A steady motif throughout this period is the correlation between the leniency the jurors were accused of showing in cases of «honour crimes» and the spread of criminality. It is precisely upon this correlation that the public defender Rakopoulos based his denunciation in 1955 of the emotionality of the jurors in cases of «honour crimes», which we saw above. «The enormous spread of crime in Greece in recent times is an extremely disconcerting phenomenon. Where are we going, Gentlemen of the jury? Have you ever examined this issue, will you examine it or will you limit yourselves simply to seeking out mitigating circumstances? If we continue in this way, people will soon be committing murder in Stadiou Street ${ }^{44}$. On the whole, jurors take the line of acquitting defendants» ${ }^{45}$.

The issue was seen to preoccupy public opinion and in any event it appeared repeatedly in the press. In 1954, it also caused the intervention of the Minister of Justice Kleanthis Theophanopoulos, who issued a circular to the presiding judges and the public prosecutors of the courts of appeal and the courts of misdemeanours advising them to pass harsher sentences on criminals and to take measures to have heinous crimes brought to court ${ }^{46}$. Similar actions were carried out by the Minister of Justice Konstantinos Kallias, in $1961^{47}$.

41 In these interventions it was acknowledged that the issue of the jury was not just a Greek problem, but was also to be found in many European states. Given the constitutional guarantee of the institution, changes were not possible without a constitutional revision. However, the proposal that met with the greatest acceptance was the one that underscored the need for the system to be transformed from a jury 
system to a mixed jury and judge system. That is to say, the body called upon to reach a verdict concerning the guilt or innocence of the perpetrator was not to be made up solely of jurors, but judges were also to participate in it $^{48}$. The times were considered ripe, especially when a popular magazine of that period clearly expressed the view that the institution of the jury was «a useless, romantic relic of the supposedly democratic need for the people to be represented in the administration of justice» ${ }^{49}$.

The proposal to replace the jury system with a mixed one was supported mainly by members of the judiciary and was discussed regularly at the conferences and the plenary sessions of the Supreme Court of Appeal. The plenary session of 1961, for example, noted that the recognition that «the jury system did not satisfy the public feeling of justice» emerged as early as 1937 without, however, convincing the members of Parliament to introduce its reform into the Constitution of 1952. In the opinion of the judges, "criticism of juries» was justified mainly «because of the inordinate leniency which the jurors display in the assessment of blame of the individual they have termed as the guilty defendant». The members of the jury «never cease to seek everywhere and always find mitigating circumstances, justifying a diminished sentence even in cases where, given the facts and the court hearing, this is unforgivable». A graver consequence was the fact that «this [...] strongly cultivates a tendency towards self-redress, which is the number one enemy of law and order» ${ }^{50}$.

If the main enemy of law and order is self-redress, then «honour crimes,» which are above all acts of self-redress, should be handled with great severity. There was a unanimous admission that the trial of similar crimes revealed the inefficiencies of the jury system in all their glory. Consequently, the main method of dealing with this phenomenon became, in the 1960s, the systematic contestation of the perception of honour on which these crimes were based and of the common cultural base which linked the perpetrators to the jurors that judged them.

This is what T. Papakonstantinou attempted to do when, in 1960, he denounced «the unacceptable, selfish mentality of men» which is responsible for «honour crimes» and demanded that the penalties for such crimes became more severe ${ }^{51}$. As we have seen, he was not the only one to establish a negative correlation between «honour crimes» and «male-dominated perceptions». However, a more categorical answer was given by Ioannis Anastasiadis, a neurologist and psychiatrist, to a question by Lena Doukidou, the young journalist of Ikones magazine, in 1964: «Recognising as a man's right and as a mitigating circumstance to commit murder in such cases [i.e. «honour crimes»], merely expresses the weaker position of woman in our society. (And even when the perpetrator is a woman, again this kind of crime usually expresses her subordinate position. A woman kills when somebody takes away her 'honour' and does not marry her - 'honour' in the sense that has been imposed by male-dominated perceptions). [...] The acknowledgement of mitigating circumstances in murders committed 'for reasons of honour' constitutes a corroboration of the fact that we still live in the world of men and indeed in conditions that are accepted by women too. Women themselves, after all, are the main obstacle to their liberation $»^{52}$. At that point, the strong emotional reaction to the victim's insults invoked by the perpetrator of an «honour crime» to justify her or his action had already lost its legitimacy. Moreover, the common value system that made this reaction and its consequences comprehensible to the perpetrator's social environment, to the newspapers' readers, to the court that tried it, and indeed to the jury, was altogether invalidated and denied. 

implied the contestation of the emotions which, according to the perpetrators, were caused by the insult to their honour and which were registered in the violence of their reactions. It also implied the contestation of, or at least the invalidation of the common value system which linked the perpetrator of an «honour crime» to the jury that tried it. It called, therefore, for a change in the «emotional regime» of social and gender relations in a way that juxtaposed emotions and reason; violence and law. It referred, in other words, to a policy of emotion management ${ }^{53}$.

This procedure reached its peak during the sixties. It was primarily expressed in public discourse contesting, all the more frequently and explicitly, the meaning of the honour that was related to the homonymous crimes. It was a discourse that challenged tradition but it was authoritarian with regard to the modernisation it professed, which aimed at constituting new disciplines and at regulating social relations «from above.» In that sense, it registered with clarity the circumstances of the post-civil-war period. However, the sixties were not only marked by a planned effort to change perceptions which were considered obsolete. They were also accompanied by a distinct decrease in those acts of interpersonal violence for which the perpetrators invoked «reasons of honour.» New forms of interpersonal violence made their appearance and began to spread, mainly between strangers, while, all the more frequently, alternative measures to violence were chosen in dealing with instances perceived as slights of honour, such as recourse to justice. Discourse and practice were then - as they always are indissolubly connected and constantly in the process of interaction.

\section{BIBLIOGRAPHY}

Anagnostopoulos, I.G., Vathiotis, K.I. (Eds), Поэvıкó $K \omega ́ \delta \imath \kappa \alpha \varsigma$ [Penal Code], Athens, P.N. Sakkoulas Publications, 2001, $2^{\text {nd }}$ edition, pp. XXXVII-XCIV.

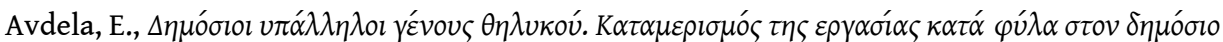
$\tau о \mu \varepsilon ́ \alpha, 1908-1955$ [Civil Servants of Female Gender. Sexual Division of Labour in the Public Sector, 1908-1955], Athens, Foundation of Research and Culture of the Commercial Bank of Greece, 1990.

Avdela, E., 'Pour cause d'honneur': violence interpersonnelle et rapports de genre en Grèce dans les années 1950-1960, in Bard, C., Chauvaud, F., Perrot, M., Petit, J.-G. (Eds), Femmes et justice pénale, XIX $X^{e}-X X^{e}$ siècles, Rennes, Presses Universitaires de Rennes, 2002a, pp. 163-171.

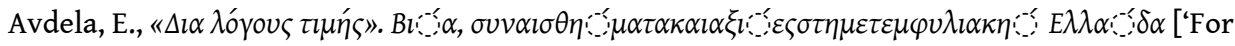
Reasons of Honour. Violence', Emotions and Values in Post-civil-war Greece], Athens, Nefeli Publications, 2002b.

Avdela, E., Between Duties and Rights: Gender and Citizenship in Greece, 1864-1952, in Birtek, F., Dragonas, Th. (Eds), Citizenship and the Nation State: Greece and Turkey, London, Frank Cass Publications, 2005, pp. 117-143. 
Boschi, D., Homicide and Knife Fighting in Rome, 1845-1914, in Spierenburg, P. (Ed.), Men and Violence: Masculinity, Honor Codes and Violent Rituals in Europe and America, 17th-20th Centuries, Columbus, Ohio, The Ohio State University Press, 1998, pp. 128-158.

Bourke, J., Fear and Anxiety: Writing about Emotion in Modern History, History Workshop Journal, 2003, 55, pp. 111-133.

Campbell, J.K., Honour, Family, and Patronage. A Study of Institutions and Moral Values in a Greek Mountain Community, New York and Oxford, Oxford University Press, 1964.

Caulfield, S., In Defence of Honor. Sexual Morality, Modernity, and Nation in Early-Twentieth-Century Brazil, Durham \& London, Duke University Press, 2000.

Close, D. (Ed.), The Greek Civil War, 1943-1949. Studies of Polarization, London and New York, Routledge, 1993.

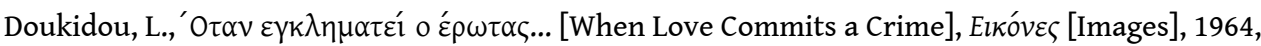
472, pp. 22-24.

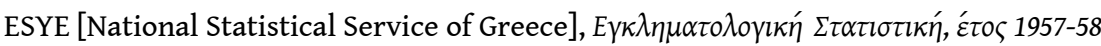
[Criminological Statistics, year 1957-59], Athens, National Printing House, 1961.

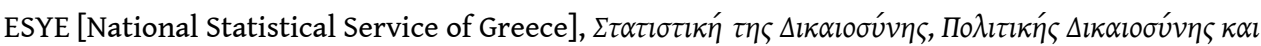

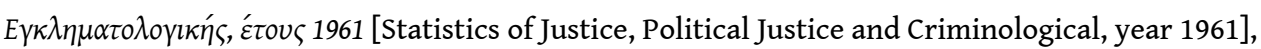
Athens, National Printing House, 1964.

Foucault, M., Surveiller et punir. Naissance de la prison, Paris, Gallimard, 1975.

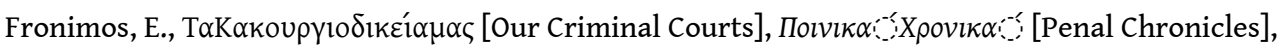
1960, X, p. 62.

Gallant, T., Murder in a Mediterranean City: Homicide Trends in Athens, 1850-1936, Journal of the Hellenic Diaspora, 1997, 23, 2, pp. 9-11.

Gallant, T.W., Honor, Masculinity, and Ritual Knife Fighting in Nineteenth-Century Greece, The American Historical Review, 2000, 105, 2, pp. 359-382.

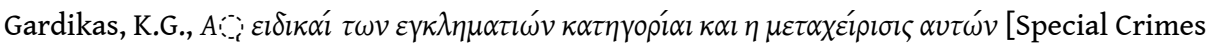
Categories and Their Treatment], Athens, Nik. A. Sakkoulas Publications, 1951.

Harris, R., Murders and Madness: Medicine, Law, and Society in the Fin de Siècle, Oxford, 1989.

Johnson, L.L., Dangerous Words, Provocative Gestures, and Violent Acts. The Disputed Hierarchies of Plebeian Life in Colonia Buenos Aires, in Johnson, L.L., Lipsett-Rivera, S. (Eds), The Faces of Honor. Sex, Shame, and Violence in Colonial Latin America, Alburquerque, University of New Mexico Press, 1998, pp. 127-151.

Johnson, L.L., Lipsett-Rivera, S. (Eds), The Faces of Honor. Sex, Shame, and Violence in Colonial Latin America, Alburquerque, University of New Mexico Press, 1998.

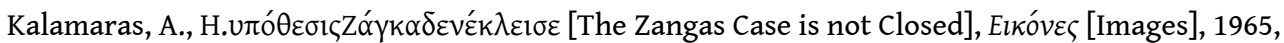
505, pp. 12-18.

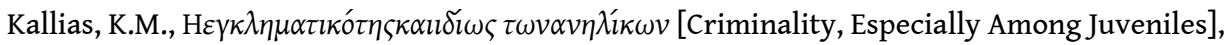
Athens, National Printing-House, 1961.

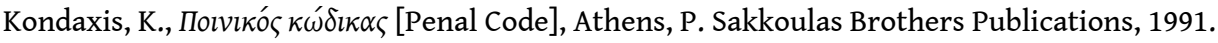




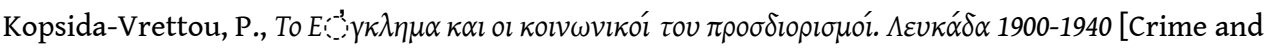
Its Social Definitions. Lefkada 1900-1940], Athens and Komotini, Ant. N. Sakkoulas Publications, 1998.

Makris, J., Ethnography, History and Collective Representation: Studying Vendetta in Crete, in de Pina-Cabral, J., Campbell, J. (Eds), Europe Observed, Oxford and London, Macmillan-St Anthony's 1992, pp. 56-72.

Malagardis, A.N., Пoıvıкós Nómos [Penal Law], Athens, G.I. Vasileiou, 1926.

Mazower, M., Inside Hitler's Greece. The Experience of Occupation, 1941-1944, New Haven and London, Yale Univeristy Press, 1993.

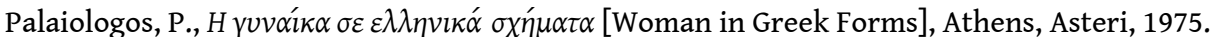

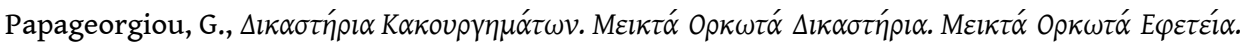

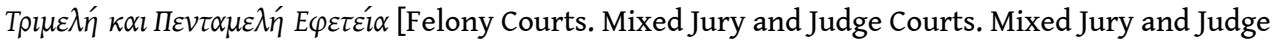
Courts of Appeal. Three- and Five-member Courts of Appeal], Athens and Komotini, Ant. N. Sakkoulas Publications, 1988.

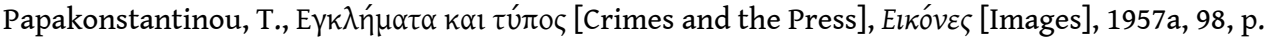
8.

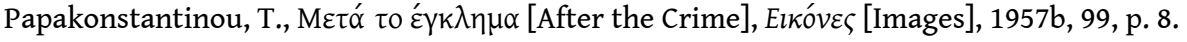

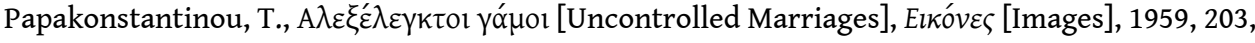
p. 21.

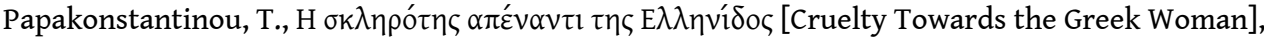
Eıкóves [Images], 1960a, 237, pp. 18-19.

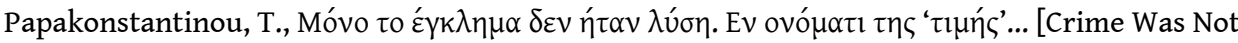
the Solution. In the name of 'honour'...], Eıkóves [Images], 1960b, 238, p. 15.

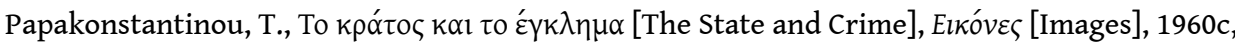
263, p. 14.

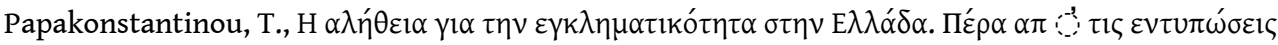

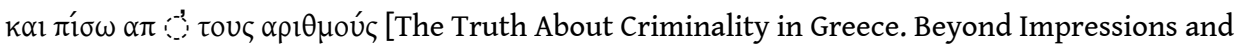
Behind the Numbers], Elкóves [Images], 1961, 298, p. 17.

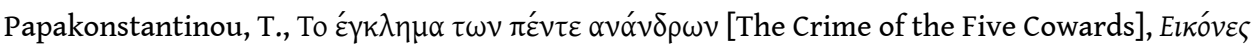
[Images], 1962, 369, pp. 26-29.

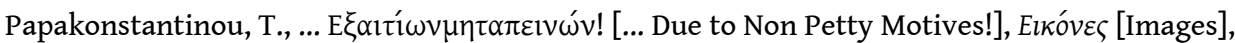
1964a, 454, pp. 12-13.

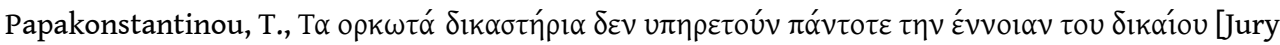
Courts Do Not Always Serve the Meaning of Justice], Eıkóveৎ [Ikones], 1964b, 462, p. 13.

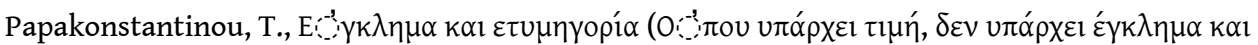
ó there is no crime, and where there is crime, there is no honour)], Eıkóves [Images], 1965a, 496, p. 25.

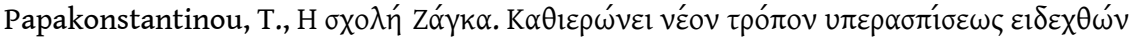

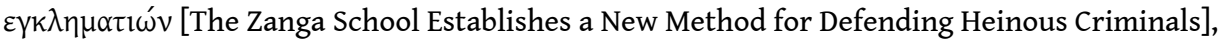
Eıкóves [Images], 1965b, 512, pp. 26-27. 


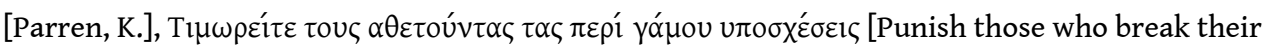

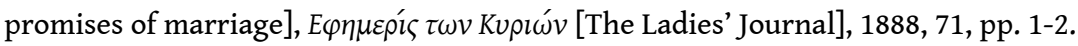

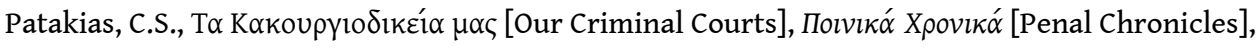
1959, IX, p. 493.

Polk, K., When Men Kill. Scenarios of Masculine Violence, Cambridge, Cambridge University Press, 1994.

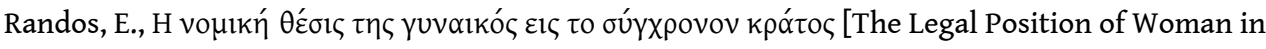

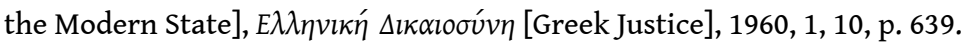

Reddy, W.M., The Invisible Code. Honor and Sentiment in Post Revolutionary France, 1814-1848, Berkeley, Los Angeles, University of California Press, 1997.

Reddy, W.M., The Navigation of Feeling. A Framework for the History of Emotions, Cambridge, Cambridge University Press, Cambridge, 2001.

Shapiro, A.-L., Breaking the Codes. Female Criminality in Fin-de-Siècle Paris, Stanford, Stanford University Press, 1996.

Smith, A., Murder in Jerba: Honour, Shame and Hospitality among Maltese in Ottoman Tunisia, History and Anthropology, 2004, 15, 2, pp. 107-132.

Spierenburg, P., Knife Fighting and Popular Codes of Honor in Early Modern Amsterdam, in Spierenburg, P. (Ed.), Men and Violence: Masculinity, Honor Codes and Violent Rituals in Europe and America, 17th-20th Centuries, Colombus, Ohio, The Ohio State University Press, 1998, pp. 103-127.

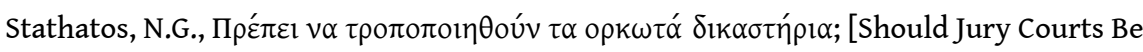
Modified?], Evos [Nation], 13.7.61, p. 1.

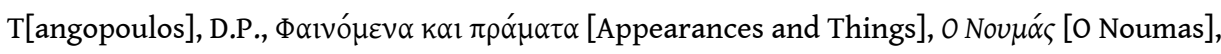
1906, V, 180.

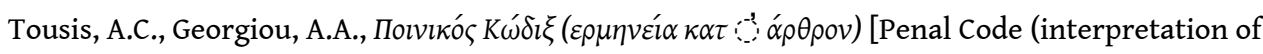
articles)], Athens, Brs D. Tzaka, 1967, $3^{\text {rd }}$ edition, pp. 266-268.

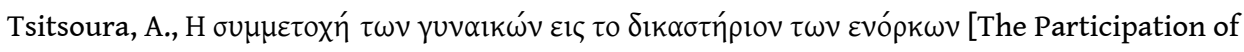

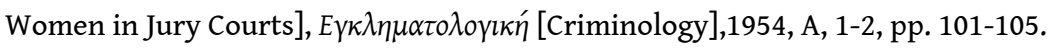

Vavaretos, G.A., Полviko sNo

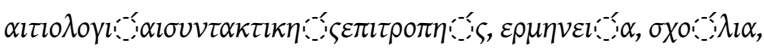

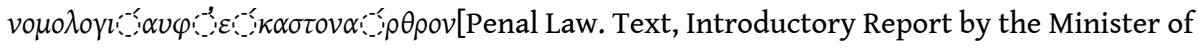
Justice, Rationale of the Editorial Committee, Interpretation, Comments, Jurisprudence of Each Article], Athens, 1956.

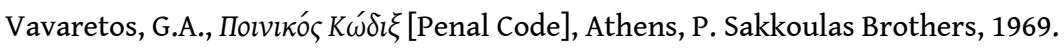

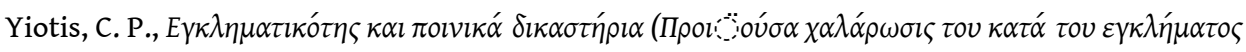
$\alpha \gamma \omega ́$ vos [Criminality and Penal Courts (The Advanced Relaxation of the Struggle Against Crime)], Athens, 1962.

\section{NOTES}

2. Kathimerini, 21/9/1951, p. 4 and 22/9/1951, p. 4.

3. For more on this matter see Avdela 2002a and Avdela 2002b. It should be noted, however, that in the case of Greece, so-called «honour crimes» differ greatly from the violent clashes caused by 
the competitiveness of manhood which, in numerous cultures, is linked to the "worship of masculinity.» Thus, they do not include the popular forms of «honour contests,» such as the verbal insults that result in brawls, arguments and stabbings, which take place in specific places of entertainment or in the neighbouring public streets and are accompanied by the consumption of alcohol. During the period we are studying, these brawls are not termed «honour crimes» by anyone. See, among others, Gallant, 2000; Spierenburg, 1998; Boschi, 1998; Johnson, 1998. In the case of Greece, «honour crimes» are also completely different from «vendettas,» even though it is not rare for the perpetrator of a crime which concerns a vendetta to invoke «reasons of honour» with a view to greater leniency on the part of the jury. See Makris, 1992. Since the «honour crimes» mentioned here are those which are declared as such, our approach is also different to the one chosen by Smith 2004. Of interest are the similarities but also the differences with the case of Brazil, as it emerges in Caulfield, 2000.

4. Gallant, 1997; Kopsida-Vrettou, 1998.

5. For more on the period, see Close, 1993; Mazower, 1993.

6. It is well known that Greece constitutes one of the research fields for the anthropological elaboration of the concept of «honour» as an organising principle of social relations, which was long considered a typical feature of «Mediterranean societies.» One of the first and leading studies to underscore the social and political significance of «honour» was carried out by Campbell, 1964, who researched the Sarakatsani, a nomadic mountain community of Epirus between 1954-1955. See also Avdela, 2002b.

7. The material used in this paper draws from the sources of Avdela, 2002b. They include four daily newspapers of Athens, court records from seven different regions of the country, and an extended number of contemporary publications, including the legal press, other periodicals as well as anthropological and sociological studies on Greek society. Court records have not been systematically preserved in Greece. Those from Athens, Amfissa, Piraeus and Chalkida for the period 1940-1970 are kept in the Central Service of the National Archives of the State, in Athens. All others from the same period are to be found in the archives of the local Courts of Appeal and their preservation is contingent on the space available. Here the records from the courts of appeals of Thessaloniki, Patras and Chania have also been used.

8. This does not apply only to the post-war Penal Code (henceforth: PC) but also to the previous ones. The new PC was ratified by Law 1492/17/7.8.1950 and was enforced in January 1951. See Anagnostopoulos, Vathiotis 2001, pp. XXXVII-XCIV.

9. Crimes against life, which are felonies, i.e. homicide, attempted homicide and bodily harm, were tried, at that time, in specific felony courts, called Kakourgiodikeia. See Papageorgiou, 1988.

10. As will become clear later in this paper, the constantly recurring argument in the fifties that the crime rate in Greece was increasing was not substantiated by statistical evidence. Crime statistics for the years 1957-1958 and 1961, the only available for the period under investigation, show a rather stable rate of homicides of all kinds and a slight decrease in cases of bodily harm. See ESYE, 1961, 1964. At the turn of the decade commentators note that the period is marked more by a qualitative diversification of crimes committed than by an increase in the crime rate. For more on the matter, Avdela, 1992b, pp. 184-200.

11. T[angopoulos] 1906.

12. Respectively: Kathimerini 22.11 .50 , p. 3; Vradyni 21.3.58, p. 6; Kathimerini 3.5.60, pp. 7-8; Vradyni 19.2.58, p. 8; Vradyni 24.2.56, p. 6; Vradyni 21.11 .59 , p. 6. In regard to the invocation of «momentary insanity» in cases of homicide attributed to extreme feelings of humiliation, as in the case of violent acts by men and women, see Harris, 1989, as mentioned by Reddy, 1997, p. 238. Also, different essays in Johnson, Lipsett-Rivera, 1998, as well as Shapiro, 1996 and Polk, 1994.

13. General State Archives (henceforth: GSA), Court Archives, Athens Mixed Jury and Judge Court, Athens Assessors' Records and Judgements (henceforth: Athens Assessors), vol. 56 (1953), No. 43a, 44, 45, 46 / 23-29.11.1953.

Crime, Histoire \& Sociétés / Crime, History \& Societies, Vol. 10, n² | 2006 
14. GSA, Court Archives, Piraeus Mixed Jury and Judge Court, Piraeus Assessors' Records and Judgements (henceforth: Piraeus Assessors), vol. 61 (1955), No. 38, 39 / 24-25.10.1955.

15. PC 1950: article 299. Concerning the length of temporary imprisonment (five to twenty years), see article 52. Through this differentiation, the new PC replaced the distinction between murder and manslaughter provided for in the old one. For the old PC, see Malagardis, 1926. For the new PC, see Vavaretos, 1956.

16. Vavaretos, 1956, p. 53. See also «Introductory Report to the Bill placing the Penal Code into effect,» inVavaretos, 1969.

17. Foucault, 1975.

18. Gardikas, 1951, pp. 18-20. PC, article 36, 37. According to the PC, a medical opinion is necessary only in cases of a complete lack of liability. Diminished liability is not an acquittal but a guilty verdict with mitigating circumstances; the same applies to a state of confusion, which falls under diminished liability. So unusual was the presence of psychiatrists in Greek courts, that when in the mid sixties trials for murders with intent between strangers began to multiply and the first trials of «ogres» - whom the defence presented as «psychopaths» - began to take place, the reaction of both the public and the press was often particularly intense. See Papakonstantinou, 1965b and Kalamaras, 1965.

19. For mitigating circumstances, see article $84 \mathrm{PC}$, par. 1 and 2. The quotations are from Kondaxis, 1991, pp. 763-767. The interpretative wording concerning mitigating circumstances is identical in Tousis, Georgiou, 1967, pp. 266-268.

20. Vavaretos, 1969, p. 3.

21. Obviously, the state of the dispensing of penal justice cannot be separated from the political repression of the time which often took on the form of penal punishment.

22. For analyses of honour from the viewpoint of Greek jurisprudence of the time, see Avdela, $2002 \mathrm{~b}, \mathrm{ch} .4$.

23. «Penal issues» is the name given to the questions posed to the jurors during a penal trial and to which they are asked to answer «yes» or «no.» The defence as well as the public prosecutor, but also the civil prosecution had a say in the way they were worded, while the responsibility rested with the judges.

24. GSA, Court Records, Amfissa Mixed Jury and Judge Court, Amfissa Assessors Records and Judgements, vol. 29 (1952), No. 14, 15 / 8.10.1952

25. GSA, Athens Assessors, vol. 56 (1953), No. 43, 44, 45, 46 / 23-29.11.1953.

26. GSA, Athens Assessors, vol. 58 (1954), No. 10, 11, 12 / 5.11.1954.

27. GSA, Athens Assessors, vol. 75 (1963), No. 31, 32, 33, 34 / 16-17.5.1963.

28. Other parameters which refer to the penal procedure itself mitigate the responsibility of the jurors and do not allow us to express a substantiated opinion on the degree of the jurors' severity or leniency in «honour crime» trials. Firstly, the jury's verdict consists of their acceptance or rejection of the so-called "penal issues,» i.e. the questions that are directed at them and which are formulated by a collaboration of the prosecution and the defence according to the specifics of the case, and to which questions the jury must reply «yes» or «no.» Secondly, the sentence that corresponds to the jury's verdict is determined by the judges within the framework of the very wide margins provided by the law; indeed, certain jurists believed that the margin of penalties for each offence in Greek penal law was so wide that the apportionment of a sentence ultimately became a subjective matter for the judges. Thirdly, the public prosecutor always has the option of requesting that the judges declare a jury's verdict «misled,» and during the period we are examining this was exercised quite often, even though it did not always have the result desired by the public prosecutor. For cases in which the jury's verdict was declared «misled,» see GSA, Athens Assessors, vol. 39 (1950), No. 19, 20 / 11.2.1950; Kathimerini 23.4.53, p. 6; Vradyni 28.10.58, p. 6; Kathimerini 24.1 .67 , p. 10. For cases in which the relevant proposal of the public prosecutor's was overruled by the judges, see GSA, Athens Assessors, vol. 40 (1950), No. 8, 9, 10, 11, 12, 13 / 
13-14.4.1950; GSA, Athens Assessors, vol. 56 (1953), No. 43a, 44, 45, 46 / 23-29.11.1953; GSA, Athens Assessors, vol. 59 (1955), No. 28, 29, 30, 31, 32, 33, 34, 35, 36 / 24.1.-8.2.1955; Patras Court of Appeals Archive (henceforth PCAA), Patras Assessors' Records and Judgements (henceforth: Patras Assessors), year 1956, No. 88, 89, 90, 91 / 22-23.9.1956. For the only case found in which the proposal to declare the verdict «misled» came from the counsel for the defence, see GSA, Patras Assessors, year 1963, No. 73, 74, 75, 76 / 21-23.1.1963 (concerning the sentencing of the perpetrator's wife for collusion).

29. Ephemeris ton Kyrion [Ladies' Journal], 66, pp. 6-7; also [Parren] 1888.

30. Vradyni, 18.2.1955, p. 5.

31. This was Legislative Decree 3075/6/9.10.54 «on amending and supplementing codified Law 5026 'on Criminal Court'», in force as of 1.1.55. After the passing of the Law granting women the right to vote, representatives of women's associations presented a memorandum in which they asked for the lifting of the restrictions which were based on women's lack of political rights. One of these restrictions prohibited women from participating in juries. The Bar Association and the General Attorney interceded in the relevant discussion caused by this demand on the part of women's associations. See the relevant news reports in Kathimerini: 27.2.53, p. 4; 24.5.53, p. 6; 13.5 .53 , p. $4 ; 13.8 .54$, p. $6 ; 26.9 .54$, p. 7 . For the conjuncture in relation to women's political rights, see Avdela, 1990.

32. Kathimerini, 26.9.1954, p. 7.

33. Tsitsoura, 1954, p.101.

34. Tsitsoura, 1954, p. 104.

35. Randos, 1960, p. 639.

36. It should be emphasised that in the case of Greece, women were not the principal victims of «honour crimes,» despite the fact that the opposite was a common occurrence in the 1960s, as shown by the references below. See Avdela, 2002a. However, it is important to stress that in the conjuncture of the time, the acknowledgement that women possess sound judgement did not lead to the contestation of male authority in the family: it co-existed with its enactment by the new civil code of 1946. The granting of equal political rights to women in 1952 and 1953, from which the discussion regarding women jurors originated, did not imply equal civil or social rights as well. See Avdela, 2005.

37. This latter assessment was expressed unanimously at Greece's annual Courts of Appeal Public Prosecutors conference, under the presidency of the Minister of Justice, K. Kallias, on 19 and 20 June, 1961 (Kallias, 1961, p. 15).

38. Fronimos, 1960, p. 62.

39. Patakias, 1959, p. 493.

40. Papakonstantinou, 1964a. Papakonstantinou, 1960 b.

41. With regard to the same crime, see Palaiologos, 1975, pp. 131-133, 134-136, 137-139, which includes a collection of the columns written for To Vima daily newspaper by well-known journalist Pavlos Palaiologos. For other cases of «honour crimes» which gave rise to social analyses, see Papakonstantinou, 1959 and Papakonstantinou 1965a, as well as Palaiologos, 1975, p. 110-112, 122-124, 125-127.

42. During the German occupation of Greece between 1941 and 1944, in the - mostly rural and mountainous - areas that were placed gradually under the authority of the left-wing National Liberation Front, a system of «popular justice» was instituted, where differences, grievances and litigation were settled by the village general assembly. The functioning of this «popular justice» system, especially during the Civil War of 1946-1949, was considered by the right-wing winners of the war as an indicator of social anarchy and as responsible for crimes against «the nation». See Mazower, 1993.

43. Papakonstantinou 1957a; 1957b; 1960c; 1961; 1964a; 1964 b.

44. One of the major streets crossing central Athens. 
45. Vradyni, 18.2.1955, p. 5.

46. Kathimerini: 9.6 .1954 , p. 5 ; 4.11.1954, p. 5; 7.11.1954, p. 8.

47. Kathimerini, 29.3.1961, p. 3; Kallias, 1961.

48. Stathatos, 1961; Kallias, 1961, pp. 13, 15, 24-33; Yiotis, 1962, p. 24.

49. Papakonstantinou, 1962.

50. Kallias, 1961, p. 15. For the restriction of the role of the jurors to be enforced, the judiciary had to wait until the dictatorship of 21 April 1967: one of its first acts was to convert the jury system of penal justice into a mixed jury and judge court (Papageorgiou, 1988).

51. Papakonstantinou, 1960a.

52. Doukidou, 1964.

53. The term «emotional regime» belongs to Reddy, 2001, pp. 111-132. See also Bourke, 2003.

\section{ABSTRACTS}

The 1950s in Greece were marked by a rash of «honour crimes» and by an extensive public debate on their penal management. The public interventions revolved around the emotions of the perpetrators and the jurors and had two aspects. One concerned the legal structure of honour as an emotion, described as intervening at the moment of the criminal act, and its assessment by the jury as a mitigating circumstance. The second referred to the emotions expressed by the jurors through their verdicts and explored to what degree these registered the existence of a cultural value system shared by the perpetrators and the jurors judging them. The muchdiscussed leniency which was systematically attributed to the jurors trying «honour crimes» gradually led, in the 1960s, to the contestation of the jury system of penal justice.

En Grèce, les années 1950 furent marquées par une vague de « crimes d'honneur » et par un large débat public concernant leur traitement pénal. Les interventions publiques touchaient aux émotions des auteurs et des jurés et comportaient deux aspects: le premier visait le caractère juridique de l'honneur comme émotion intervenant lors du passage à l'acte, et son appréciation en tant que circonstance atténuante, par le jury; le second renvoyait aux émotions exprimées par les jurés dans leur verdict et au point de savoir dans quelle mesure ce dernier traduisait un système de valeurs et une culture commune aux auteurs et aux jurés chargés de les juger. Le laxisme systématiquement attribué aux jurés dans ces procès conduisit graduellement à la remise en cause de l'existence du jury criminel, dans les années 1960.

\section{AUTHOR}

\section{EFI AVDELA}

Professor of Contemporary History, Department of History and Archaeology, University of Crete, Rethymno 74100, Greece, eavdela@otenet.gr

I wish to thank the two anonymous referees of this journal for their comments which helped me improve my arguments. Efi Avdela is Professor of Contemporary History at the University of

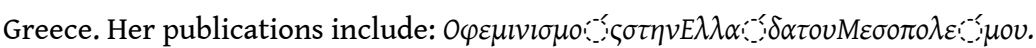

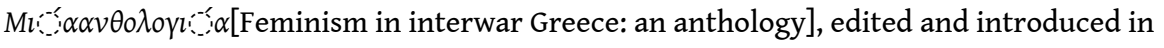




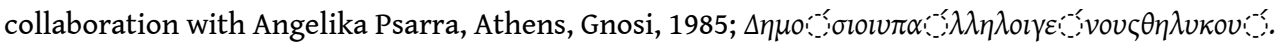

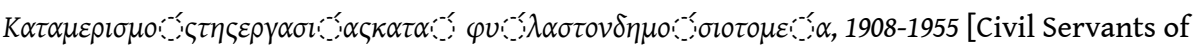
Female Gender. Sexual Division of Labour in the Public Sector, 1908-1955], Athens, Foundation of Research and Culture of the Commercial Bank of Greece, 1990; $\Sigma 1 \omega \pi \eta \rho \varepsilon$

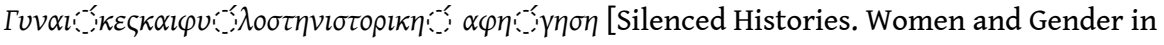
Historical Narrative], edited and introduced in collaboration with Angelika Psarra, Athens,

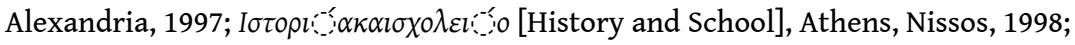

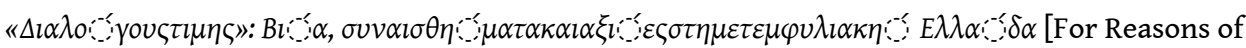
Honour: Violence, Emotions and Values in Post Civil-War Greece], Athens, Nefeli, 2002; Le genre entre la classe et la nation: essais d'historiographie grecque, Paris, Syllepse, 2006. 